\title{
CHURCHES AS A STOCK OF SOCIAL CAPITAL FOR PROMOTING SOCIAL DEVELOPMENT IN WESTERN CAPE COMMUNITIES ${ }^{1}$
}

\author{
BY \\ IGNATIUS SWART \\ (Unit for Religion and Development Research, University of Stellenbosch)
}

\begin{abstract}
The aim of the article is to present a perspective on the manner and extent to which churches may be considered as an important stock of social capital for promoting social development outcomes in selected communities in the Western Cape, South Africa. Taking the recently presented policy outline on social capital formation in this province as the contextual framework for analysis and reflection, the results of recently executed demographic and socio-empirical research are utilised in particular to advance a perspective on churches. It is argued in conclusion that churches and other faith-based organisations in the researched communities have an important strategic significance for a social capital formation agenda, despite their apparent lack of progressive social praxis. Their comparative advantage over other institutions, the considerable levels of trust invested in them and the manner in which they inspire activities of voluntary outreach, caring and social service are highlighted as special features of the churches.
\end{abstract}

\section{Introduction}

There are several reasons why the topic of this article can be considered to be important:

Firstly, in South Africa no other social institution can claim to command the same level of public trust as the Christian churches. This fact was highlighted in recent surveys by the Human Sciences Research Council of South Africa (HSRC 2000) ${ }^{2}$ and is frequently used by advocates of religion to promote an argument about this sector's social strength. In particular, it has been argued that churches and other faith-based organisations should be regarded as most strategic in contributing to the challenge of moral regeneration and reaching the South African population at large (see Erasmus \& Mans 2005:141-142; Hendriks, Erasmus \& Mans 2004:382; Koegelenberg 2001:104-105; Louw \& Koegelenberg 2003:13; URDR 2004a:4-5; b:4-5; 2003:7-8).

Secondly, the perspective on social trust has also been extended to a wider debate on the strategic importance of churches and the faith-based sector in general as an agent of social development in post-apartheid South Africa. Prominent role players such as the National Religious Association for Social Development (NRASD), the Ecumenical Foundation of Southern Africa (EFSA) and the National Religious Leaders' Forum (NRLF) have in this regard promoted an argument about the extensiveness of religious social welfare networks in the country, their capacity to reach out to and serve the people most in need, and the value-laden nature of their social programmes (Koegelenberg 2001; Louw \& Koegelenberg 2003; cf. Swart 2005a). In turn this argument has evoked various positive responses from representatives of government and the state, who have affirmed the importance of churches and other faith-based organisations as a strategic partner in the field of social development (see Hendriks et al. 2004:382; Koegelenberg 2001:105-6, 108; Ministry of Social Development 2004a; b; Swart 2005b; URDR 2004a:4-5; b:4-5; c:4-5; 2003:7-8).

Thirdly, in South Africa a strategy of social capital formation is shifting to the centre of social development policy discourse. To date such a strategy has been most explicitly and comprehensively formulated in the 'Social Capital Formation Document' of the Western Cape Provincial Department of Social Services and Poverty Alleviation (hereafter Department), which was made available to participants at a workshop on social capital at the University of the Western Cape in February 2005. ${ }^{3}$ In essence, in this document a strategy 
of social capital formation is promoted as an important tool for public sector intervention to meet the challenge of social exclusion and provide disadvantaged communities with access to networks and socio-economic opportunities. For the Christian churches and the faithbased sector in general, the document could be seen as of important significance for the way in which it comes to identify a 'value-based approach' as a crucial constituent of a social capital formation strategy. Accordingly, social capital formation is associated directly with the kind of strategic action that will revive the traditional values of 'ubuntu' and 'neighbourly love', that is, values that in turn could be seen as foundational to meeting the social capital goals of social cohesion and inclusion (Department 2005:5).

Fourthly, in the international academic debate about the relationship between social capital and development increasing interest is shown in the role of churches and other faithbased organisations as agents of social capital formation. In the proliferating corpus of literature on the theme strong empirically founded arguments are being presented about the strategic role that faith-based traditions and their associated organisations - such as churches - are playing in mobilising the kinds of social capital that lead to communal actions of collective social outreach and caring. In a nutshell, it is postulated that these traditions and their organisations are not only a necessary source of the social capital values of cooperation, social connectedness and trust that are required, but in some instances could also be regarded as the single most important factor ${ }^{4}$ of social capital formation and activity in certain communities (see e.g. Bacon 2004; Brown \& Brown 2003; Candland 2000; Farnell 2001; Hays 2002; Kennedy, Schorr, Warren \& Wilson in Murphy \& Cunningham 2003:211-213; King \& Furrow 2004; Prins \& Ewert 2002; Putnam 2002; Silverman 2002; Smith 2002; Uslaner 1997; Yeung 2004a, b; 2003).

This article seeks to contribute to the ongoing debate (see e.g. Koegelenberg 2001; Louw \& Koegelenberg 2003; Swart 2005a) on the role of the faith-based sector in meeting the challenge of social development in South Africa. In the light of the above motivation the innovative aspect of such an anticipated contribution will in particular be the way in which the strategic potential and role of local churches in the field of social development are newly interpreted within the conceptual framework of social capital.

In other words, and viewed from the vantage-point of the indicated new policy interest in the concept of social capital in the country, the aim of the article is to present a perspective on the way and extent to which churches in particular may be considered as an important stock of social capital to promote social development outcomes at the community level. Drawing firstly on the above-mentioned 'Social Capital Formation Document' in order to construct a relevant contextual framework for analysis and reflection, a key element of the discussion will be to present and utilise the results of recently executed demographic and socio-empirical research in selected communities in the Western Cape by the Unit for Religion and Development Research (URDR) at Stellenbosch University as the basis for advancing a perspective on churches. Finally, by interpreting the research results in terms of the constructed framework, the church sector's potential and actual contribution to meaningful social capital formation in their communities - i.e. specifically in the Western Cape - will be considered critically.

\section{Social capital application in the Western Cape}

In attempting to initiate a discussion on the topic of social capital that is specific to the context of the Western Cape province and also takes root in the ongoing debate about social development in the country, the Western Cape Provincial Department of Social Services and Poverty Alleviation's above-mentioned 'Social Capital Formation Document' can be taken as an important point of reference.

Suggesting that the conceptual framework of social capital will take an important place in the future design and planning of social development policy in the Western Cape, a closer study of this document reveals how a perception of social exclusion guides its promotion of 
social capital as a strategic concept in a fundamental way. In an extensive situational analysis of socio-economic conditions in the province, the document highlights the fact that the Western Cape context ought to be seen as one of extreme inequality and contrast between rich and poor that exceed those in all other provinces despite higher than average economic growth, perceived wealth creation and development ${ }^{5}$ (Department 2005:9). Furthermore, for the document this situation of vast disparities between different communities is particularly highlighted by a whole range of social indicators. 'Whilst the wealthiest communities [in the province] live in comfortable first world conditions and have good health indicators', it bemoans the fact that 'the poorest live in conditions comparable with some of the worst found in developing countries and have very poor health indicators' (Department 2005:11). In addition those deprived communities are also plagued by severe problems with regard to housing, child abuse, street children, youth involvement in crime, alcohol and drug abuse, criminal gangs, education, early childhood development, truancy, older persons, violence against women, services to the disabled and HIV/Aids (Department 2005: 11-16).

Yet it is important to note how for the document the problem of social disparity is most seriously reflected by a similarly unequal distribution of resources and social services among different communities. In this regard, it comes to highlight the fact that in terms of social worker resources most 'are located in geographical areas that have traditionally received most of the resources'. This state of affairs is sharply contrasted with the traditionally marginalised areas such as Khayelitsha, Mitchell's Plain and Beaufort West (i.e. so-called Presidential nodal areas) that 'are still heavily under-resourced in terms of social worker provisioning' (Department 2005:18). In all, for the document '[f]ar-flung areas such as Murraysburg and Laingsburg have very little social service infrastructure', whilst the general trend in 'areas of greatest need' is one of 'ad hoc service delivery' (Department 2005:18-19). As the document further comments:

This trend is... substantiated by comments raised during recent imbizo processes that suggest sporadic social service presence in marginalised communities. As one speaker in Grabouw commented: "The social worker... visits here only once a month and then only for a couple of hours in the morning" - a clear indication that services are not reaching where it is most needed. (Department 2005:19)

It is against the backdrop of this situational analysis that the document's use and application of the concept of social capital should be understood. As already pointed out in the introductory section above, in this document a strategy of social capital formation is promoted as an important (if not essential!) means or tool to address the prevailing gross inequalities and in the process ensure that the hitherto excluded communities obtain newfound access to opportunities, resources and information (Department 2005:12, 22). Moreover, as the means or tool to achieve this proclaimed goal of social inclusion, it becomes clear that:

(i) Social capital formation as a strategic process more than anything else refers to the strengthening and establishment of social networks that will mediate the new-found access to opportunities, resources and information. In terms of the familiar typologies of social capital, it becomes clear that the document comes to favour the notion of linking social capital - a third type of social capital that in the debate about social capital is distinguished from the notions of 'bonding' and 'bridging social capital'. ${ }^{9}$ Consequently, an understanding of social capital is likewise applied that anticipates newly established connections between the hitherto excluded communities (those without power and resources), on the one hand, and government as well as more affluent communities or sectors (those in possession of power and resources), on the other hand. Through these newly established connections it is furthermore anticipated that resources, services and opportunities will be redirected (or distributed) to the former communities to the extent that they will foster 
meaningful development and further social capital formation (Department 2005:3, 5, $6,12,23-26)$.

(ii) Social capital formation as a strategic process simultaneously also refers to the strengthening and establishment of relationships, norms and values as the means towards realising the new state of social inclusion. However, in this framework of understanding these entities are not merely perceived as additional elements to the network element, but they define the essential nature, cumulative effect and outcomes of the social networks in action. Consequently, we are presented here with an understanding whereby existing and created social capital - in particular social networks - accumulate further social capital. As a result of their value-laden and relational inclination, the social networks in action are depicted as the activating source of traditional South African values such as 'ubuntu' and 'neighbourly love' that, in turn, become foundational to realising the new reciprocal relationships between communities and inspire the actions of actual redress (Department 2005:3, $5,23)$.

(iii) Social capital formation further entails the notion of social trust as a fundamental outcome. As such the notion of trust particularly appears to capture the new relationship that exists between communities but also between spheres of government and communities as a result of the process of social capital formation. At the same time, however, it also appears to capture the fundamental new social condition in which a process of social capital formation can actually flourish and strategic partnerships between the various social actors can become the actual means whereby the goals of development and distribution are met (Department 2005:3, 23).

(iv) Government/the Department of Social Services and Poverty Alleviation, social workers and social development workers are singled out as the social facilitation agents of the anticipated social capital formation process. In this regard it is first of all required of the above-mentioned department to reassess its own social service delivery network and, accordingly, facilitate the redirection of this network and its resources to areas of greatest need and highest priority. In turn it is also required that social workers and social development workers will be appropriately redeployed within this network in order to become facilitators of poverty strategies, programmes and connections between different departments and other spheres of government and resources. In such a strategic framework it furthermore becomes apparent how the role of social development workers as brokers of information about the concerns of communities to service networks is especially emphasised. In addition, this line of thinking also brings the document back to a perspective on the role of the abovementioned department as 'social activist'. It is emphasised that in this role the department should play a more concerted role as advocate for poor people and their rights and responsibilities. Within the strategic mould of linking social capital formation, this would mean that the department should also advocate the needs of the poor to the relevant authorities and departments outside its own jurisdiction (Department 2005:23-25).

(v) Social capital formation as a strategic process is finally directly associated with a developmental approach to addressing people's social needs. Thus it is emphasised that the social networks that are strengthened and established through social capital formation should by themselves have a developmental impact. Amongst other things, such networks should generate distinctive developmental outcomes, such as those anticipated by strengths- and community-based approaches to social development, capacity-building and holistic modes of intervention, human capital and skills development, substance-abuse prevention and the establishment of saving schemes and cooperatives. Furthermore, as integral to a comprehensive agenda to 
transform social service delivery, a social capital formation strategy should be directed to the following critical areas that have been prioritised for intervention: services to the disabled; services to older persons; integrated provincial poverty reduction strategy; early childhood development; youth development; increased accessibility of government services, information and resources; integrated response to HIV/Aids; research; services to children and families; substance-abuse services (Department 2005:4, 25-29).

In so far as we are taking the 'Social Capital Formation Document' as a guiding framework in this article to develop a perspective on local churches as a strategic actor of social capital formation, it has become clear from the above analysis that a concern about prevailing gross socio-economic inequalities and skewed distribution of resources, opportunities and information between different communities stands at the centre of the document. In terms of the strategic perspective following from such concern, we have furthermore seen how the concept of 'social capital formation' has come to be understood in terms of the notion of 'linking social capital' as the strategic means whereby new connections with privileged communities and institutions of power are established that would simultaneously enable a redirection of resources and opportunities for development to deprived communities. As indicated by our analysis, a particularly significant aspect of this perspective is also the role allocated to government as the primary enabling agent of the social capital formation strategy. In this regard, we have encountered an example of government and the state not delegating responsibility to other actors (as critics of the social capital concept and its application hold) (see Harriss 2002:111-123), but of a specific department of government claiming primary responsibility to act as an activist for poor people's rights and needs and, accordingly, redirecting its own network of services in order to meet those rights and needs (Department 2005:23-25).

However, viewed from the particular interest of this article to develop a perspective on churches, it is the latter recognition - and indeed appreciation - of government's strategic role in a process of socio-economic redress that also brings us to the point of stating what could be regarded as an important shortcoming of the 'Social Capital Formation Document'. By appearing in essence, as has become clear from our analysis, to be a strategic document in the first place for a specific governmental actor, but secondly also for social workers and social development workers, one is left with the question as to what role there could be for other actors in the envisaged social capital formation strategy. Indeed, this question becomes particularly relevant when one, for instance, considers the strategic challenge captured by the social capital formation notions of 'relationships' and 'values' in the document. Whilst one can fully concur with the document that there is a fundamental enabling role for government to play in the social capital formation process, one in which social workers and social development workers also have a very important facilitating role to play, it at the same time also seems very doubtful that these actors could be primarily responsible for mediating the deeper processes of relational and value formation that are asked for.

This article departs from the thesis that a process of social capital formation can only be successfully realised through the collective participation of all institutions and actors in society. In aiming to contribute to this perspective specifically from the point of view of the faith-based sector, the approach is furthermore not one in which certain aspects of a social capital formation strategy are viewed as providing the sole mandate for particular actors, but rather one in which the various aspects or dimensions are seen as being interrelated and the mutual responsibility of the collectivity of social actors. Applied to the Christian churches, whilst an argument about their participation in a social capital formation strategy will naturally entail a consideration of their contribution or potential contribution to the relational and value foundations of the kind of social capital formation strategy asked for above, this will not be done in isolation from the other dimensions that we have identified. 
In particular, in terms of our constructed framework of analysis, we are here also interested in developing a perspective on the nature and extent of local churches' own service delivery and development activities, the kind of connections that are fostered through such activities, and the levels of trust towards which they (local churches) might be contributing to as a basis for meaningful social capital formation and development activity.

\section{Researching churches and social needs in local communities}

Since its establishment as an interdisciplinary centre of research in the Faculty of Theology at Stellenbosch University in $2001^{7}$, the Unit for Religion and Development Research (URDR) has undertaken a number of research initiatives ${ }^{8}$ to mobilise the faithbased sector for social development action in local communities. Having confined itself to date to an engagement with communities in the Western Cape province, the defining feature of the Unit's research work has been the way in which it has consistently striven to engage members of the various communities as direct participants in the research through a participatory action research process (see Erasmus, Hendriks \& Mans 2004; Swart 2005b). On the basis of this principle of participation the Unit's research could furthermore be described as essentially an attempt:

(i) To obtain first-hand insight into the acute social needs and problems in the communities on the basis of members' own experience;

(ii) To establish more directly from members how many people in their respective communities, including themselves, were involved in services rendered by churches and other organisations or received assistance;

(iii) To establish first-hand from members how they perceive the role of the church as a social service agent in their communities;

(iv) To establish more closely from members the kind of networks and partnerships within which churches operate in the process of social service provision (cf. Erasmus \& Mans 2005; Erasmus et al. 2004; Hendriks et al. 2004).

Against the above essential background of the nature and purpose of the URDR's research work, this section highlights seven aspects of the dissemination process that were communicated in feedback sessions to the communities and could be taken as relevant to the purpose of this article: 
(1) Presenting a visual orientation of churches' strategic potential in local communities:

Figure 1: Orientation map and places of worship in George

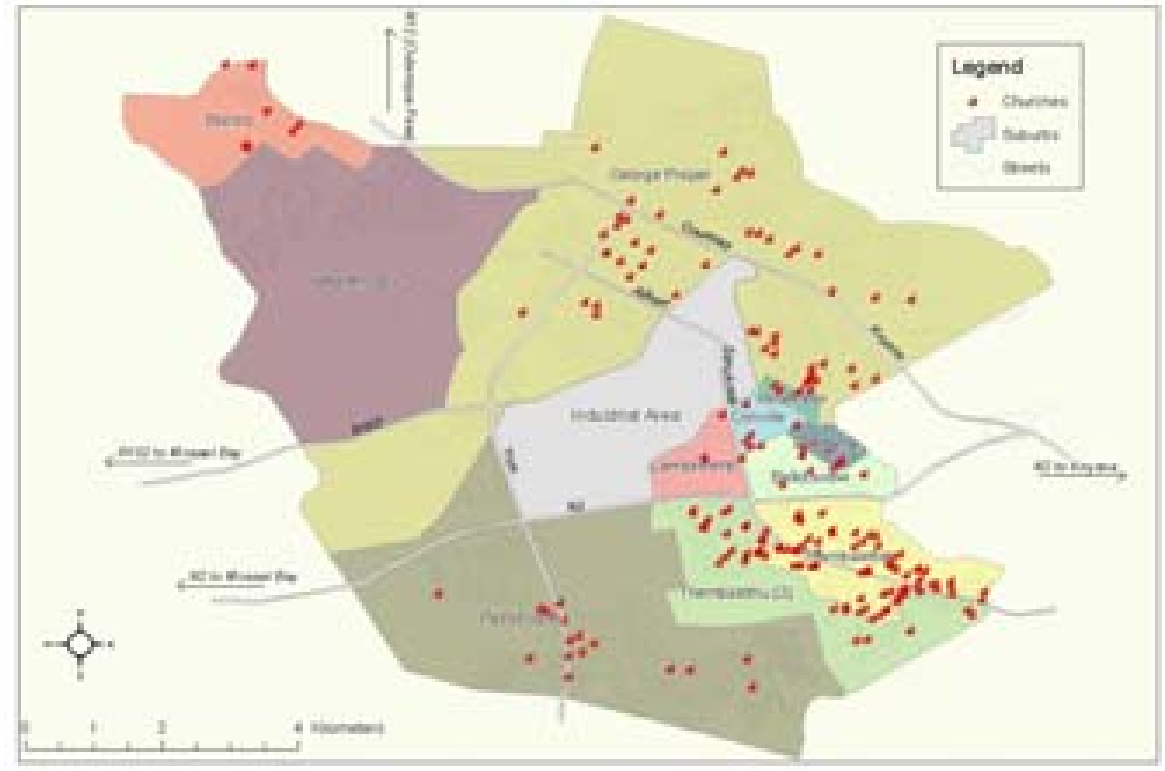

In the URDR's research process as a whole GPS (Global Positioning System) and GIS (Geographical Information Systems) technology has played a most strategic role not only in the actual conducting of the research but also the diffusion of the research results (see Swart 2005b). This technology was described in a recent appreciation as one that especially allows those in the social service fields 'to analyze and present results in a visually meaningful and appealing way through the use of maps' (Queralt \& Witte 1998:457). Figure 1 shows, among other things, how the combination of GPS and GIS technology enabled URDR researchers to present a visual display of the places of worship in the various communities in their feedback (cf. Swart 2005b:7-8). Presenting in this case the example of the community of George, Figure 1 illustrates a feature that has consistently repeated itself in the research done in the different communities. Although it is not possible to show on the map the total of 231 churches in the George community, it is nevertheless clear from the 'church buildings' indicated on the map that churches are - with the exception of one area (Heather Park) - particularly well distributed and represented across the whole community. In turn, based on this visual evidence the fact of the church's comparative advantage has been argued. This supports the hypothesis that churches are probably the only organisations that could claim to have contact with virtually every household in this community (and in the other researched communities, as the GPS results have similarly shown) (URDR 2003:15; see also Erasmus \& Mans 2005: 145, 157; Swart 2005b:8-9; Hendriks et al. 2004:390-391, 399; URDR 2004a; b; c). 
(2) Showing the occurrence of a particular social problem:

Figure 2: Prevalence of HIV/Aids in George

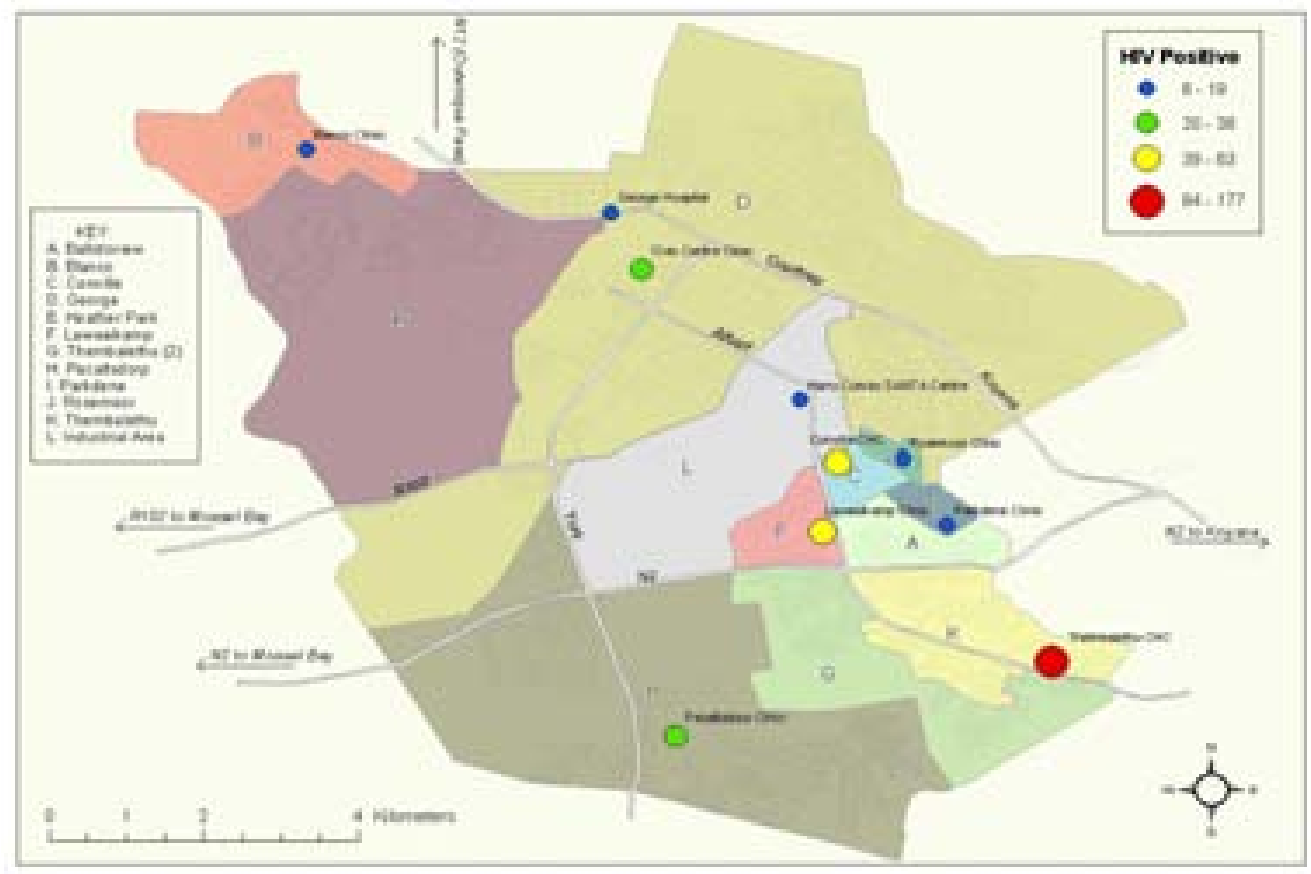

Applying GIS technology has enabled the URDR researchers also to use the maps of orientation to present members of the communities with a visual display of the areas of greatest need in their communities. As illustrated by Figure 2, with regard to the problem of HIV/Aids, for instance, data obtained from the local Health Services office could be used to show to participants in the feedback sessions in George where most people were suffering from HIV/Aids in their community (see URDR 2003:15-18, 22, 37; cf. Hendriks et al. 2004; Swart 2005b:11-12; URDR 2004:a; b; c). From this vantage point it now also becomes possible to further highlight the strategic significance of the church sector in this community - as could be done in the other researched communities on the basis of similar results (cf. e.g. URDR 2004 a; b; c; Hendriks et al. 2004; Erasmus \& Mans 2005). By relating the map with the HIV/Aids data to the map in Figure 1, it could be shown to the participants that those areas with the largest number of HIV/Aids cases, such as the black township of Thembalethu in particular, are similarly areas with a very high density of churches (cf. Swart 2005b:14). 
(3) Reporting on the degree of involvement and assistance received:

Figure 3a: Assistance to victims of sexual violence and crime through direct involvement in Paarl

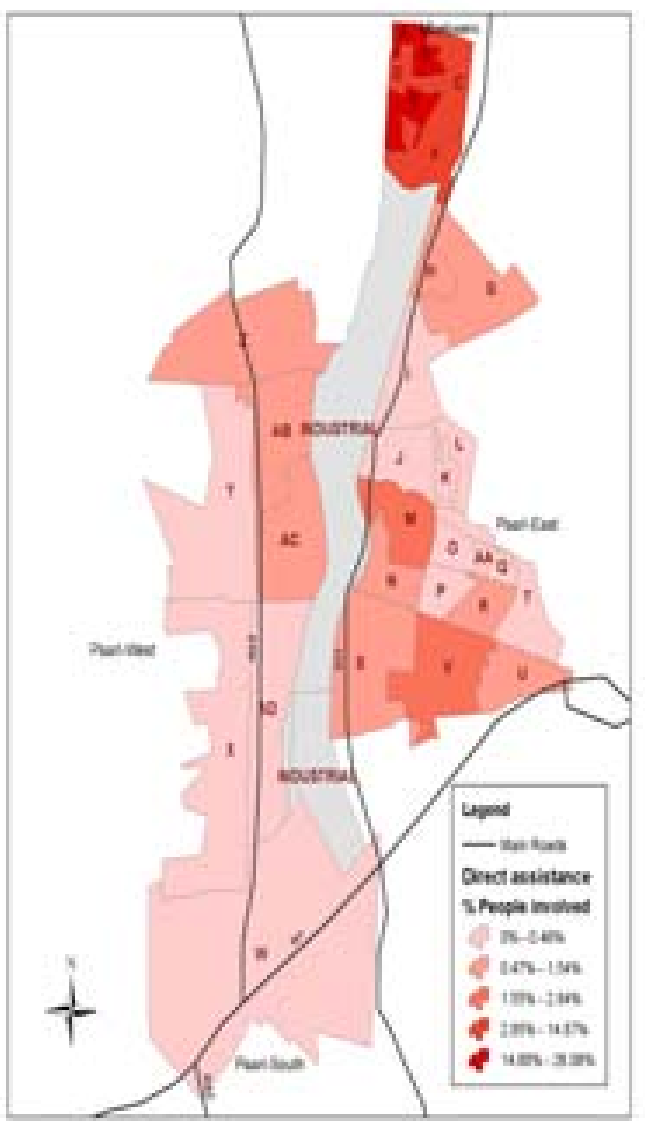

Figure 3b: Places of worship in Paarl

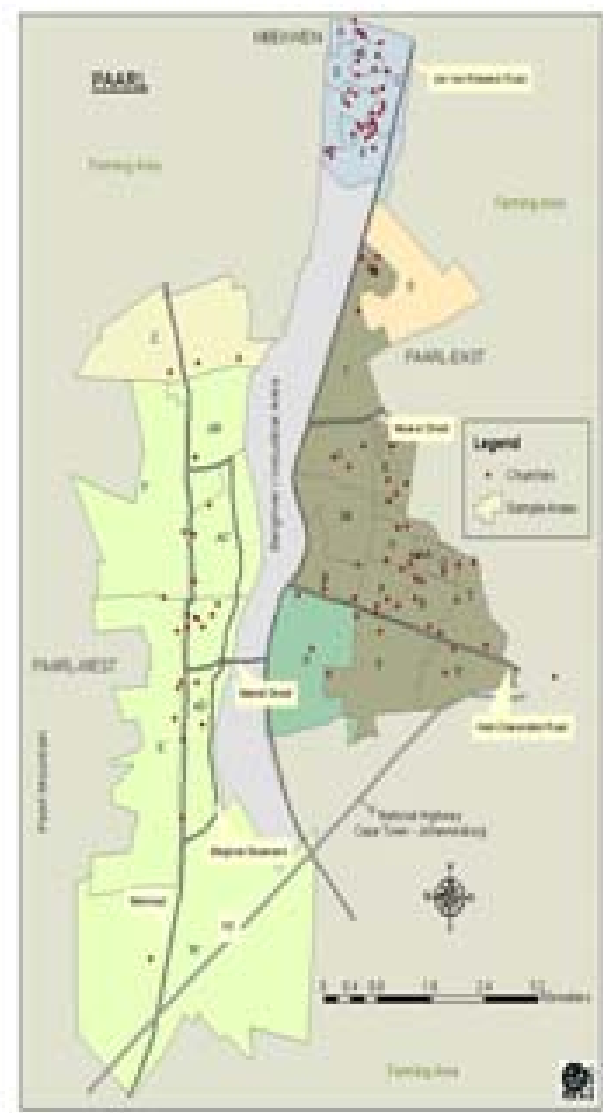

In the URDR research conducted in the communities of Paarl and George a questionnaire survey distributed amongst $10 \%$ of the households in every sample area was strategic in generating information about various aspects related to the social problems that were prioritised by community members as the areas of greatest concern: HIV/Aids, unemployment, sexual and violent crime, and substance abuse. As indicated by the tables in the Appendix, the threefold purpose of the investigation was to establish the number of people involved in services rendered by churches and other organisations, the number who receive assistance, and the perceptions of the community concerning the churches' involvement in social services (see Erasmus \& Mans 2005:145-146; Erasmus et al. 2004:58; Hendriks et al. 2004:387-388; Swart 2005b:9-10; URDR 2003:11-13).

Turning more specifically to the dissemination of the research, Tables $1,2,7 \mathrm{a}$ and $7 \mathrm{~b}$ reveal that three kinds of activities have been measured in the Paarl community with regard to people's involvement and the assistance received by people: direct, preventative and counselling (cf. Erasmus \& Mans 2005:146). Although scoring relatively similar average percentages, the results show, amongst other things, that most people appear to have volunteered their services in direct action. Most people also seem to have volunteered their services in the HIV/Aids field and to have received assistance in the same field.

As shown by Figure 3a, GIS technology likewise became a very useful tool to communicate these aspects of the research results to participants in the feedback sessions (cf. Swart 2005b:11-13). By putting the data in Table 7a into a GIS geodatabase, for instance, it could be indicated on the map of orientation where people were actively assisting victims of sexual and violent crime. In the case of Paarl, one of the significant 
indicators resulting from such application is that people seemed to be mostly involved in the black township of Mbekweni (Erasmus \& Mans 2005:151), the area that has also shown the highest density of churches as illustrated by Figure $3 b$.

(4) Reporting on people's perceptions about the role of the church:

Figure 4: People's perceptions about the church's involvement with the problem of sexual and violent crime in Paarl

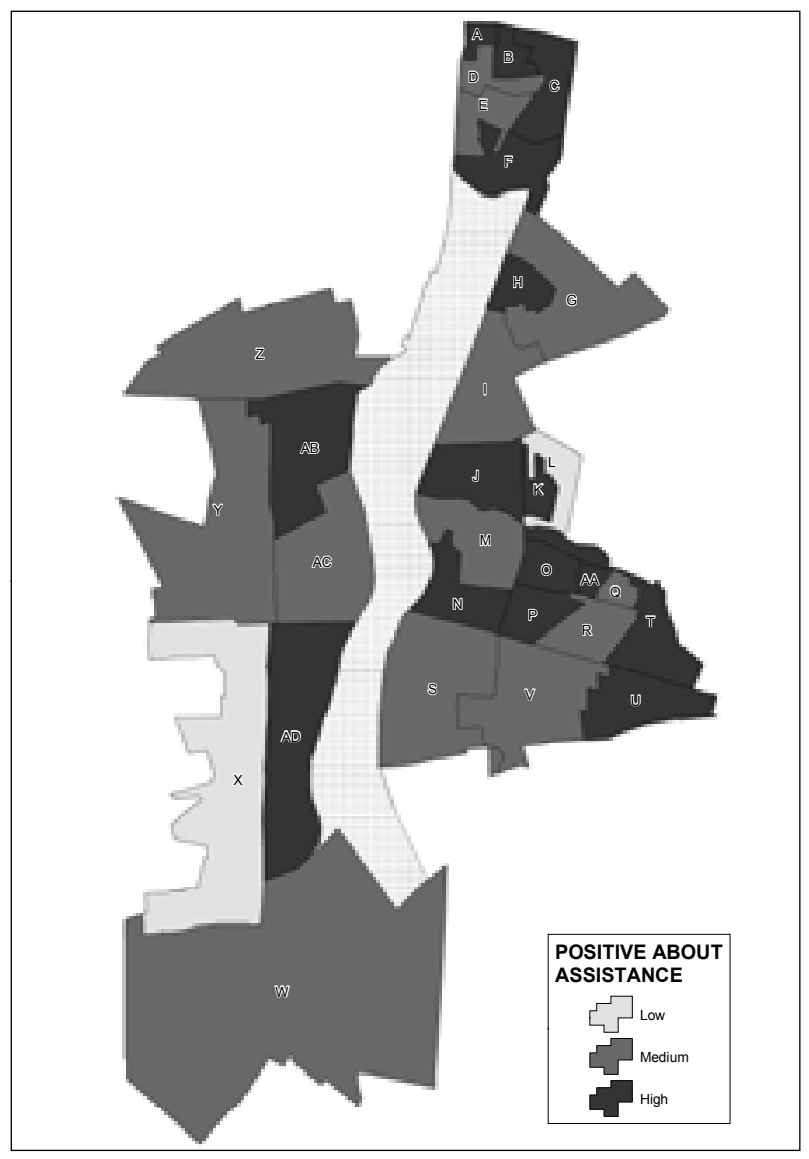

It follows from the information presented in the rest of the tables in the Appendix $(3-6,8)$ that numerous conclusions could also be drawn with regard to people in the Paarl community's perceptions about the churches' involvement with the identified social problems. Indicating in general that people in this community appeared overwhelmingly positive about the church as a social role-player, the data further reveal, amongst other things, that people especially valued the churches' involvement in the area of counselling and the specific issue of sexual and violent crime (cf. Erasmus \& Mans 2005:147). The larger majority of respondents also disagreed with the statement that the church does not care for the poor, whilst the overwhelming majority felt strongly about the fact that churches should cooperate both with government and NGOs.

As in the previous instances, Figure 4 above shows how the GIS technology once again proved an effective means to communicate the results of this aspect of the questionnaire survey. On the map in this figure, which reflects the data in Table 8 , the majority of dark areas clearly show the community's overwhelmingly positive perception with regard to the churches' active involvement with the problem of sexual and violent crime (cf. Erasmus \& Mans 2005:153). 
(5) Reporting on the areas of prevailing need for service and the corresponding readiness for intervention by the church:

Figure 5a: Areas of high service need concerning sexual and violent crime in Paarl

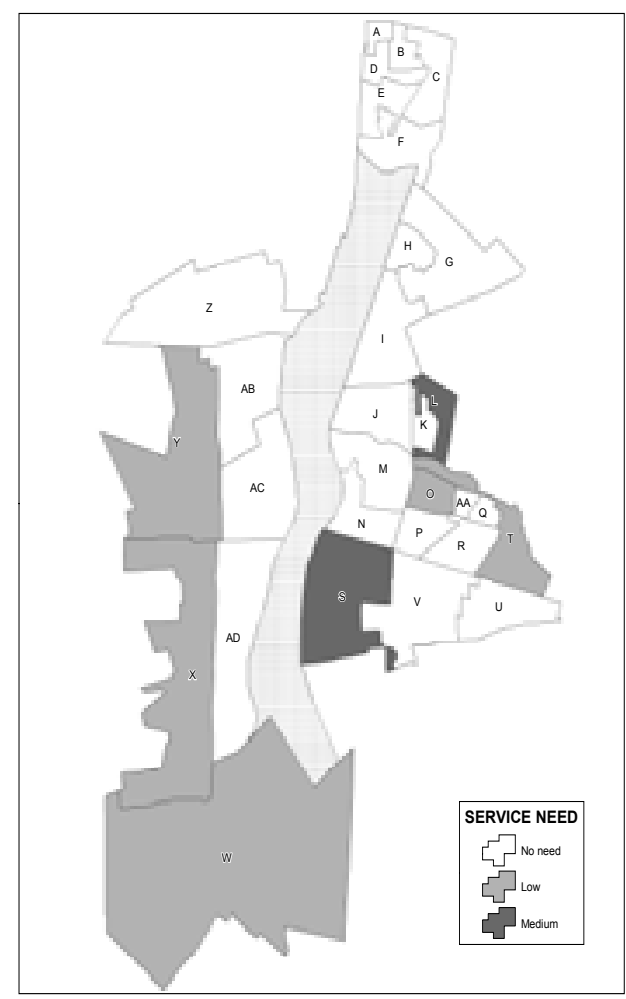

Figure 5b: Areas ready for church intervention with regard to the problem of sexual and violent crime in Paarl (intervention readiness)

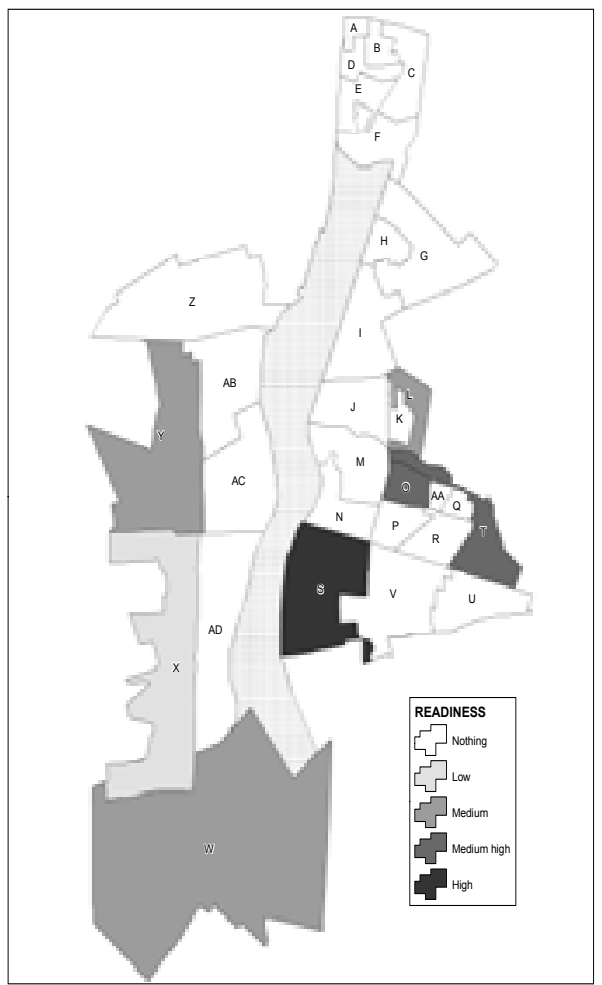

Having the data sets on the prevalence of a particular problem (cf. point (2) above), people's involvement (Table 7a), the assistance received (Table 7b) and people's perceptions about the churches' involvement (Table 8) at their disposable, subsequently also made it possible for the URDR researchers to communicate two further insights during the feedback sessions. By making different computations using these data sets ${ }^{9}$ and applying the GIS technology, Figures $5 \mathrm{a}$ and $5 \mathrm{~b}$ show how it was, for example, possible in the community of Paarl to indicate, with regard to the problem of sexual and violent crime, where the areas of greatest need and the corresponding readiness for intervention by the church in those areas were (Erasmus \& Mans 2005:151-153). According to these figures, there is clearly a strong correlation between those areas where the need for service remains high (Figure 5a) and those areas where people are highly positive about church intervention regarding the problem (Figure 5b). At the same time, it also appears from these figures that there is little need for (further) intervention in an area such as, for instance, the township of Mbekweni (sample areas A-F), despite being one of the areas with the highest prevalence of the problem (see Erasmus \& Mans 2005:158). As this is also the area with the highest density of churches in Paarl as Figure 3b shows, this evidence could be taken as further supporting the idea that churches in this area were actively involved with addressing the problem of sexual and violent crime (cf. Erasmus \& Mans 2005:153). 
(6) Reporting on the actual ministries, partnerships and networks in which churches are involved:

In the communities of Paarl and George structured interviews with a representative sample of congregational leaders constituted an important complementary element of the research process (i.e. in addition to the questionnaire survey and GPS/GIS work). Through these interviews, which included questions about the ministries, partnerships and networks in which the congregations of the targeted leaders were involved, it was possible to provide participants in the feedback sessions with more specific information regarding the actual social service ministries in their communities as well as their respective connections (Erasmus \& Mans 2005:148; Erasmus et al. 2004:8; Hendriks et al. 2004:388; Swart 2005b:10; URDR 2003:14, 53-54).

So, for instance, the 24 questionnaires that were returned in Paarl (out of a total of 30 distributed) revealed that a high number of churches (17 in total) were in some way or another involved with the problem of unemployment. Amongst these initiatives 8 congregations recorded partnerships with either NGOs or denominational offices, whilst a high number of volunteers (81 in total) appeared to be involved (Erasmus \& Swart 2005).

Regarding the issue of HIV/Aids, the results revealed that 7 congregations rendered some form of service in the Paarl community, either alone or in partnership with another organisation, or sometimes both. These services included providing blankets and clothes, visitations, counselling, food parcels, information distribution and families fostering Aids orphans. In total 98 people appeared to volunteer for these services (Erasmus \& Swart 2005; Hendriks et al. 2004:392-393).

However, the data revealed that only 2 churches rendered services to victims of substance abuse and sexual and violent crime. In both instances services seemed to be provided with other organisations, including faith-based organisations, whilst a total of 7 and 23 volunteers respectively appeared to be involved (Erasmus \& Swart 2005).

As a whole, it can be concluded that in the case of Paarl and George the results of the leadership questionnaires provided further support for the notion that churches and their members were actively involved with the identified issues in their communities. However, as the above-mentioned data on the issues of substance abuse and sexual and violent crime suggest, the results also presented a more realistic picture with regard to the actual involvement of churches. For instance, when compared to the high degree of involvement recorded through the household survey and GIS work (point (3) above), the lack of church involvement recorded through the leadership questionnaire suggested that members of churches in Paarl were rather personally involved in the problem of sexual and violent crime or through their involvement with other faith-based organisations and NGOs (Erasmus \& Mans 2005:153-154). Furthermore, the results in Paarl and George revealed that many congregations were in fact not operating on their own, but were part of different networks with other agencies (including churches and NGOs) to render their services (Erasmus \& Mans 2005:153). In many cases it seems that outside initiatives started the ministry and that congregations merely support the projects or ministries. Regarding their actual involvement, it also appears that the services of congregations have basically been confined to the provision of immediate relief. From this it could be concluded that the churches in these two communities still by and large lack the capacity to engage with the identified problems in a developmental mode (Hendriks et al. 2004:393; URDR 2003:22). 
Figure 6a: Community profile(C-Index) of needs satisfaction in Lwandle (Helderberg Basin)

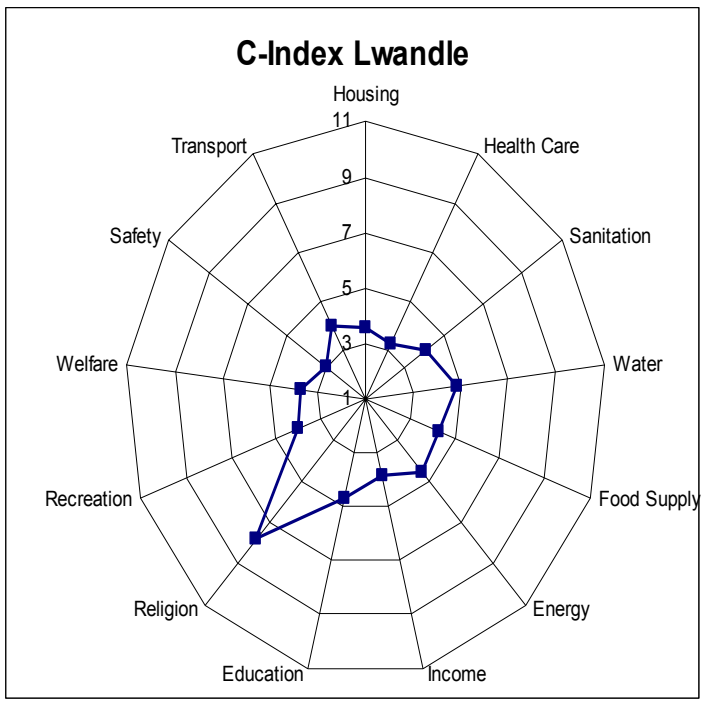

Figure 6b: Community profile(C-Index) of needs satisfaction in Eastridge (Mitchell's Plain)

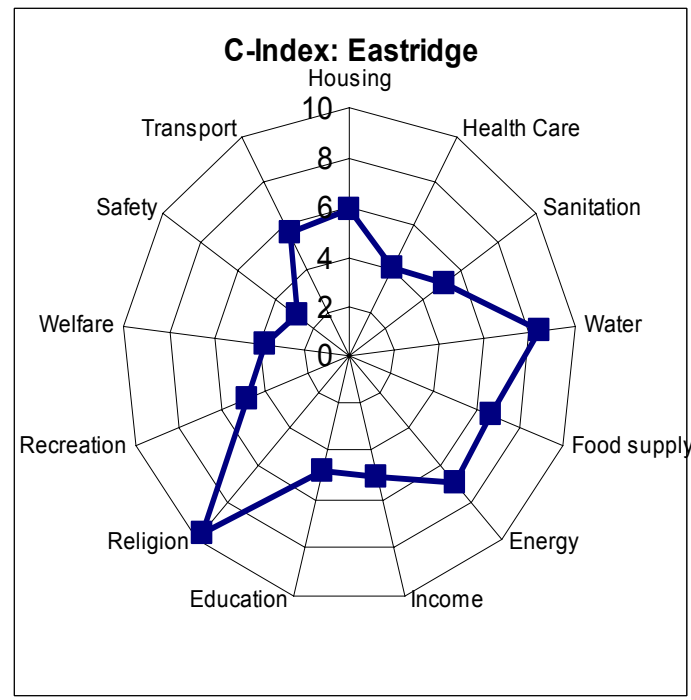

In the ongoing development of the URDR's participatory research process the generation of more qualitative data on the social needs of the researched communities has become a particularly important feature of the research (see Erasmus, Mans \& Jacobs 2005:148-149, 152-153, 155-157; Erasmus et al. 2004:8-9; Swart 2005b:1, 10; URDR 2003:13-14; 2004a; $\mathrm{b} ; \mathrm{c})$. In this regard Figures $6 \mathrm{a}$ and $6 \mathrm{~b}$ are examples of a larger effort undertaken recently by the Unit to research the social needs of communities in the whole of the Cape Peninsula ${ }^{10}$ (see Erasmus 2005a; b; Erasmus et al. 2005; URDR 2004:a; b; c). They show the results of the needs analyses in two poverty-stricken communities, the township of Lwandle in the Helderberg Basin and Eastridge in Mitchell's Plain.

As the two community profiles (C-Indexes) drawn on the basis of the respective needs analyses (cf. Schutte 2000:21-35) clearly indicate, it is evident that in both communities people have been struggling with similar social issues. In both cases residents have identified needs and services related to welfare, safety, health care, education, income, recreation and sanitation as amongst the least satisfied in their communities (i.e. on scales that range between 0 and 11 and where 10 and 11 are the highest in a positive sense). At the same time, however, it is also strikingly evident from the two profiles that religion represents the sector that has been viewed most positively by the residents of both communities (Erasmus 2005:146; URDR 2004b; 2004c:27). In both these communities, which are similarly characterised by the population's dominant affiliation to the Christian faith and a dense distribution of churches (i.e. similar to the other cases discussed in this article - Erasmus 2005:145-156; URDR 2004b; 2004c:18-20), the residents in general appear to be highly satisfied with the role that religion as a sector has been playing in their communities and in their own lives.

From a strategic point of view, the results of the needs analyses have become an important further means whereby the URDR could not only make residents and representatives from the church sector aware of the concrete needs experienced by their own people, but also highlight the potential of the churches as a social role-player in their communities. In particular, based on the level of satisfaction that they seem to command not only in the above-mentioned two communities but in most of the other researched communities, it has been argued that local churches presented a significant channel of opportunity to enter the respective communities and reach the local people (Erasmus 2005:146; Erasmus et al. 2005:162; URDR 2004a:34; URDR 2004b; 2004c:27). 


\section{Churches as a stock of social capital in Western Cape communities: a conclusion}

It seems rather obvious that a positive connection could be made between our theme of social capital in this article and the results of the URDR research presented in the last section. Following on the fourfold motivation at the beginning of this article with regard to the topic of the article, the URDR's research could especially be appreciated for the way in which it has contributed to an informed decentralised perspective on the social potential and impact of churches in local communities in the Western Cape.

From the point of view of a social capital interest, we have seen how the URDR results present us with significant visual evidence of churches' comparative advantage over other institutions in the researched communities. Having presented itself as a consistent feature of the research results, the dense and widespread location of churches shown by the URDR's GPS and GIS work strongly supports the thesis promoted by URDR researchers and prominent role-players in the social development debate (with reference to the second motivating statement in the introduction of this article) about churches' (and other faithbased organisations') potential and actual reach at the local community level. In more overt social capital language, the dense and widespread location of churches in an important way suggests that they could be a significant constituting source of social capital networks through which the most poor and deprived may be reached and the collective problems in those communities be addressed in a concerted and self-reliant manner by the people themselves. In this regard, furthermore, it has been shown by the URDR results how churches are especially well represented in those areas of the communities where people are suffering most under particular social problems.

Yet, more than any other notion of social capital, it is to the notion of social trust that various aspects of the research results could be related explicitly. A concrete localised manifestation of the first motivating statement at the beginning of this article and also identified as one of the pillars in the 'Social Capital Formation Document', we have seen from the results that the churches command the respect and appreciation of many people. For them churches are an indispensable social role-player that should be involved in the social problems of their community and intervene in those areas where services are crucially needed. They also do not bear out the view that the churches do not care for the poor and, in fact, present the churches with a strong mandate to engage in strategic activities of social capital formation, to build relationships of cooperation between themselves as well as with government and the NGO sector.

As an important addition to the URDR's research work, we have seen how the outstanding profile of the church sector as an institution of trust is perhaps best illustrated by the results of the URDR's needs analyses. Having been conducted in communities characterised by extreme poverty and deprivation, it is apparent from this aspect of the research results how the religious sector, and by implication the churches as the dominant religious institution, have by far outscored those sectors that can be associated with the other plotted needs. Based on this evidence, and as we have indicated, it has rightly been argued by URDR researchers themselves that the churches could be viewed by policy-makers and other strategists as an important channel of opportunity to enter the respective communities and establish contact with the local people.

Proceeding beyond the notion of social trust to more tangible manifestations of social capital formation and community action, the URDR results also in this regard suggest that churches in the researched communities act as generators of voluntary outreach, caring initiatives and different modes of social service across a spectrum of social needs. In particular, it appears from the results that such concrete actions are the greatest and most successful in areas where people are more exposed to the various social problems than in areas where the problems are less prevalent. 
However, as our discussion of the research results has already made partly clear, it is at this point that we also need to introduce a more critical perspective on the churches.

Firstly, whilst the research results testify that the outreach activities and structured initiatives of local congregations do convert into networks of cooperation and partnerships with other faith-based organisations and NGOs, including denominational offices, there has been little evidence that those networks and partnerships of collective action have proceeded beyond conventional activities of charity and immediate relief. Indeed, viewed from the perspective of the 'Social Capital Formation Document' that this article has identified as a guiding framework for analysis and reflection, the churches' current mode of involvement still seem to be a far cry from the development approach and outcomes that the document has set out as a fundamental characteristic of the social capital networks within its framework of understanding.

Secondly, the URDR results also suggest that a significant grey area remains with regard to the actual participation of the churches in the identified social problems. As we have come to see, there seems to be no clear correlation between the different sets of results on local people's involvement and that of the churches themselves. This inconsistency well suggests that, whilst the local churches may in many instances represent the source that inspire some kind of voluntary action, they to a lesser degree function as an actual source of voluntary outreach and social service, which may rather involve NGOs and other faithbased organisations, the family, and persons in their personal capacity with friends in the neighbourhood.

It follows from the above two critical points that this article finds no evidence from the URDR results that the churches in the researched communities could be associated with the more radical politicised strategic agenda set out in the 'Social Capital Formation Document'. In particular in those communities in which historic inequalities have by and large been maintained - such as in Paarl and George - there is no evidence that the churches are in any way involved in strategic activities of linking social capital formation that are aimed at the building of relationships across the divides and the kinds of active redress spelled out in the document. At best, where they may actually be involved, their activities of charity and relief assume some kind of superficial social capital formation.

However, this article wants to conclude that the ambivalence it has come to identify between the considerable potential of the churches as a stock of social capital formation in local communities, on the one hand, and their lack of actual progressive engagement, on the other, should not restrain those policy-makers and agencies behind the social capital formation agenda in the Western Cape from considering far more deliberately the strategic role that churches (and other faith-based organisations) may play in such an agenda. Indeed, as we have already pointed out, they remain institutions with a considerable comparative advantage over other institutions in their communities. Despite their apparent lack of progressive social praxis, they seem from the point of view of the local people to be significant channels of opportunity and bases of trust that could be mobilised for further social capital formation and the desired social development outcomes. And, most important of all, they are by their very nature and despite their shortcomings fundamentally strategic in contributing to what the architects of the 'Social Capital Formation Document' have rightly identified as a core pillar of a social capital formation strategy, namely the nurturing and revitalising of particular values and norms.

In conclusion, it is proposed that it is with the latter aspect that the churches themselves should begin when reconsidering what their innovative role might be in addressing the challenge of social capital formation. It is on this terrain that they could make their most valuable contribution and where a process of transformation and renewal should fundamentally begin for themselves. On a concrete strategic level, this should imply a renewed investment in their traditional core activities, to utilise those activities to cultivate the values that are also foundational to a social capital formation strategy and should have as 
outcome the kind of relationship formations and development actions anticipated in particular by the notion of linking social capital.

\section{Acknowledgement}

This material is based upon work supported by the National Research Foundation of South Africa under Grant number 2054070. Any opinion, findings and conclusions or recommendations expressed in this material are those of the author and therefore the NRF does not accept any liability in regard thereto.

\section{NOTES}

1. Paper prepared for presentation at the conference of ASASWEI (Association of South African Social Work Education Institutions), 'Democracy, Development, Delivery: Mapping the future contributions of the social service professions', Stellenbosch, 6 \& 7 September 2005.

2. In the two surveys that were conducted in 1999 and 2000 to determine the level of public trust in South Africa's social institutions, amongst others national, provincial and local government, political parties, business and the media, the churches recorded the highest level of trust on both occasions. On the basis of the 2000 survey only the churches and the Independent Electoral Commission (IEC) could claim to command over fifty percent of public trust, with the former scoring by far the highest percentage ( $74 \%$ trust rate) followed in second place by the IEC ( $50 \%$ trust rate).

3. This workshop, which was held on 17 February 2005, could be attended by invitation and was hosted by the University of the Western Cape's Economics Department in partnership with the Western Cape Provincial Department of Social Services and Poverty Alleviation.

4. Within the context of American society, Robert Putnam (2002), one of the pioneering thinkers in the social capital debate, has for instance concluded that faith communities could be regarded as the single most important repository of social capital. Following other authors, Brown and Brown (2003:617-618) have further supported such a stance by pointing out that 'churches are often the only nongovernmental institution' in black American communities. Moreover, they went on to argue that 'religious congregations often serve as the largest organized expression' in those communities. Compared to other voluntary organisations, people from those communities have come to "view their churches as having the best chance of alleviating social problems that plague their communities'.

5. According to the document the extremity of this situation is evident from the fact that the Western Cape heads the provincial inequality league in the country. In this province one is confronted by the fact that its ginicoefficient 'is an unacceptable high of 0.62 compared with the national figure of 0.57' (Department 2005:9).

6. In the opening discussion paper by Abdullah Bayat at the same workshop at which the 'Social Capital Formation Document' was made available to participants, these three distinctions were explicitly pointed out. Whereas 'bonding social capital' represents the construction of social networks between 'intra-groups' such as family and friends, and 'bridging capital' the construction of networks between 'extra-groups' of a more impersonal kind, 'linking social capital' represents the connections between groups 'with differing levels of power or social status'. In the latter case important examples would be the links constructed 'between the political elite and the general public or between individuals from different social classes' (Bayat 2005:4-5).

7. For further background information about the URDR's establishment and the rationale and methodology that guide its research work, see Swart (2005b).

8. These include (1) the 'Church and Community Research Project' conducted in the communities of Paarl and George (2001-2003) (see Erasmus et al. 2004; Hendriks et al. 2004); (2) the 'Transformation Research Project' conducted in communities across the Cape Peninsula (2004-2005) (see the URDR's website at http://academic.sun.ac.za/theology/egdn/trp/trp.htm); and (3) the NRF-funded research project, 'Developing a praxis for mobilising faith-based organisations for social capital and development in the Western Cape' (20042006), of which this article is a direct outcome (see the above acknowledgement and the URDR's website at http://academic.sun.ac.za/theology/urdr.htm).

9. The following two formulas were used to determine these two aspects of the research results, i.e. (1) the areas of greatest need and (2) the corresponding readiness for intervention by the church: The need for service $\{\mathrm{N}\}$ equalled the prevalence of the problem $\{\mathrm{P}\}$ minus ((providing assistance $\{\mathrm{PA}\}$ plus receiving assistance $\{\mathrm{RA}\}$ )divided by 2). N=P-[(PA+RA)/2] (Erasmus \& Mans 2005:151). Intervention readiness was determined by multiplying people's perceptions with the need for service in a given area. Readiness = perceptions $\mathrm{x}$ need for service (Erasmus \& Mans 2005:152).

10. Reference is made here to the second project mentioned in note 8 above. 


\section{BIBLIOGRAPHY}

Bacon, D. 2004. Revitalizing Civil Society through Social Capital Formation in Faith-based Organizations: Reflections from Northern Ireland. Social Development Issues 26(1):14-24.

Bayat, A. 2005. Defining Social Capital: A Brief Overview of the Key Aspects and Debates. Discussion paper presented at the Workshop on 'Social Capital'. Economics and Management Sciences Faculty, University of the Western Cape, 17 February 2005.

Brown, R.K. \& Brown, R.E. 2003. Faith and Works: Church-based sSocial Capital Resources and African American Political Activism. Social Forces 82(2):617-641.

Candland, C. 2000. Faith as Social Capital: Religion and Community Development in Southern Asia. Policy Sciences 33:355-374.

Department of Social Services and Poverty Alleviation 2005. Social Capital Formation Document. Prepared for Cabinet Legkotla, 9-10 February 2005.

Erasmus, J.C. 2005. Religion and Social Transformation: A Case Study from South Africa. Transformation 22(3):139-148.

Erasmus, J.C., Mans, G.G. \& Jacobs, C. 2005. Transformation Africa: Pray, and Work - the Role of Research, in Symington, J. (ed), South African Christian Handbook 2005-2006. Wellington: Tydskriftemaatskappy van die NG Kerk.

Erasmus, J.C. \& Mans, G.G. 2005. Churches as Service Providers for Victims of Sexual and/or Violent Crimes: A Case Study from the Paarl Community. Acta Criminologica 18(1):140-163.

Erasmus, J.C., Hendriks, H.J. \& Mans, G.G. 2004. Research Report: Church and Community Research Project [on line]. Rev. 10 August 2005. Available: http://academic.sun.ac.za/theology/egdn/RESEACH\%20METHODOLOGY_PAARL\&GEORGE.pdf.

Erasmus, J.C. \& Swart, I. 2005. URDR Results \& Social Capital. Paper presented at a URDR \& BUVTON Seminar with Prof. Nancy Ammerman, University of Stellenbosch, 23 June 2005.

Farnell, R. 2001. Faith Communities, Regeneration and Social Exclusion: Developing a Research Agenda. Community Development Journal 36(4):263-272.

Harriss, J. 2002. Depoliticizing Development: The World Bank and Social Capital. London: Anthem Press.

Hays, R.A. 2002. Habitat for Humanity: Building Social Capital through Faith-based Service. Journal of Urban Affairs 24(3):247-269).

Hendriks, H.J., Erasmus, J.C. \& Mans, G.G. 2004. Congregations as Providers of Social Service and HIV/AIDS Care. Dutch Reformed Theological Journal (NGTT) 45(2) Supplementum:380-402.

Human Sciences Research Council (HSRC) 2000. Broken Trust, a Wake-up Call for Major Institutions [on line]. Rev: 11 July 2005. Available: http://www.hsrc.ac.za/media/2000/11/20001114 1.html.

King, P.E. \& Furrow, J.L. 2004. Religion as a Resource for Positive Youth Development: Religion, Social Capital, and Moral Outcomes. Developmental Psychology 40(5):703-713.

Koegelenberg, R.A. 2001. Social Development Partnerships between Religious Communities and the State: Perspectives from the National Religious Association for Social Development (NRASD). Journal of Theology for Southern Africa 110 (July 2001):97-109.

Louw, L. \& Koegelenberg, R.A. 2003. Building a New South Africa: The Building of a Caring, Democratic and Equitable Society through Partnerships between the State and the National Religious Leader's Forum (NRLF). Position paper prepared for the NRLF meeting with President Thabo Mbeki, 29-30 April 2003. A perspective from the National Religious Association for Social Development (NRASD) [on line]. Rev. 11 July 2005. Available: http://sarpn.org.za/documents/d0000557/index.php.

Ministry of Social Development 2004a. Minister Skweyiya and Religious Leaders Agree on Closer Cooperation in Tackling Poverty, Unemployment and HIV/AIDS. Media release, 20 July 2004. Available: www.socdev.gov.za.

Ministry of Social Development 2004b. Address by Dr Zola Skweyiya, Minister of Social Development, to the Consultation on State-religious Sector Development Cooperation, Bishopscourt, 20 July 2004. Media release, 20 July 2004. Available: www.socdev.gov.za.

Murphy, P.W. \& Cunningham, J.V. 2003. Organizing for Community Controlled Development: Renewing Civil Society. Thousand Oaks: Sage.

Prins, E. \& Ewert, D.M. 2002. Cooperative Extension and Faith-based Organizations: Building Social Capital. Journal of Extension 40(3) [on line]. Rev. 19 June 2005. Available: http://www.joe.org/joe/2002june/index.html.

Putnam, R. 2002. Conclusion, in Putnam, R. (ed.), Democracies in Flux: The Evolution of Social Capital in Contemporary Society, 393-416. Oxford: Oxford University Press.

Queralt, M. \& Witte, A.D. 1998. A Map for You? Geographical Information Systems in the Social Services. Social Work 43(5):455-469.

Schutte, D. 2000. People First: Determining Priorities for Community Development. Parow: Ebony Books.

Silverman, R.M. 2002. Vying for the Urban Poor: Charitable Organizations, Faith-based Social Capital, and Racial Reconciliation in a Deep South City. Sociological Inquiry 72(1):151-165. 
Smith, G. 2002. Religion, and the Rise of Social Capitalism: The Faith Communities in Community Development and Urban Regeneration in England. Community Development Journal 37(2), 167-177.

Swart, I. 2005a. Networks and Partnerships for Social Justice? The Pragmatic Turn in the Religious Social Development Debate in South Africa. Religion \& Theology 12(1):20-47.

Swart, I. 2005b. Mobilising Faith-based Organisations for Social Development through a Participatory Action Research (PAR) Process. Maatskaplike Werk/Social Work 41(4):323-336.

Unit for Religion and Development Research (URDR) 2004a. Transformation Research Project: Paarl/Wellington. Stellenbosch: URDR. Available: http://academic.sun.ac.za/theology/egdn/trp/trp.htm.

Unit For Religion And Development Research (URDR) 2004b. Transformation Research Project: Helderberg Basin. Stellenbosch: URDR. Available: http://academic.sun.ac.za/theology/egdn/trp/trp.htm.

Unit for Religion and Development Research (URDR) 2004c. Transformation Research Project: Mitchell's Plain. Stellenbosch: URDR. Available: http://academic.sun.ac.za/theology/egdn/trp/trp.htm.

Unit for Religion and Development Research (URDR) 2003. George Aids Forum Research Report [on line]. Rev. 10 August 2005. Available: http://academic.sun.ac.za/theology/egdn/GeorgeAidsForumReport2003.PDF.

Uslaner, E. 1997. Faith, Hope and Charity: Social Capital, Trust and Collective Action. College Park: Department of Government \& Politics, University of Maryland.

Yeung, A.B. 2004a. An Intricate Triangle: Religiosity, Volunteering, and Social Capital: The European Perspective, the Case of Finland. Nonprofit and Voluntary Sector Quarterly 33(3):401-422.

Yeung, A.B. 2004b. Individually Together. Volunteering in Late Modernity: Social Work in the Finnish Church. Helsinki: The Finnish Federation for Social Welfare and Health.

Yeung, A.B. 2003. Social Capital in Church-related Volunteerism, in Seven Essays on Scandinavian Civil Society, 141-172, Stockholm: Handelshögskola. 


\section{APPENDIX: TABLES}

(A) Summary of the results from the questionnaire survey in Paarl/Mbekweni (10\% sample)

\begin{tabular}{|c|c|c|c|c|c|c|c|c|c|c|c|}
\hline \multicolumn{1}{|c|}{ Table 1: Involvement / assistance rendered } \\
\hline \multicolumn{10}{|c|}{ Direct } & \multicolumn{3}{|c|}{ Preventative } & \multicolumn{4}{c|}{ Counselling } \\
\hline$*$ SV & $* \mathrm{H} / \mathrm{A}$ & $*$ Un & Ave & SV & H/A & Un & Ave & SV & H/A & Un & Ave \\
\hline $13.7 \%$ & $12.3 \%$ & $10.2 \%$ & $12.1 \%$ & $11.2 \%$ & $15.1 \%$ & $9.3 \%$ & $11.9 \%$ & $11.7 \%$ & $13.0 \%$ & $9.5 \%$ & $11.4 \%$ \\
\hline
\end{tabular}

*SV $=$ sexual and violent crime; $*$ H/A = HIV/Aids; $*$ Un $=$ Unemployment

\begin{tabular}{|c|c|c|c|c|c|c|c|c|c|c|c|}
\hline \multicolumn{4}{|c|}{ Direct } & \multicolumn{4}{|c|}{ Preventative } & \multicolumn{4}{|c|}{ Counselling } \\
\hline SV & $\mathrm{H} / \mathrm{A}$ & Un & Ave & SV & $\mathrm{H} / \mathrm{A}$ & Un & Ave & SV & $\mathrm{H} / \mathrm{A}$ & Un & Ave \\
\hline $11.0 \%$ & $11.2 \%$ & $8.3 \%$ & $10.2 \%$ & $10.6 \%$ & $12.4 \%$ & $8.5 \%$ & $10.5 \%$ & $10.7 \%$ & $10.8 \%$ & $9.0 \%$ & $10.2 \%$ \\
\hline
\end{tabular}

\begin{tabular}{|c|c|c|c|c|c|c|c|c|c|c|c|}
\hline \multicolumn{1}{|c|}{ Table 3: Perceptions regarding the churches direct action } \\
\hline Certainly not & \multicolumn{7}{|c|}{ No } & \multicolumn{5}{c|}{ Unsure } \\
\hline SV & H/A & Un & Ave & SV & H/A & Un & Ave & SV & H/A & Un & Ave \\
\hline $1.1 \%$ & $1.2 \%$ & $1.4 \%$ & $1.2 \%$ & $4.1 \%$ & $6.7 \%$ & $6.3 \%$ & $5.7 \%$ & $18.8 \%$ & $23.1 \%$ & $27.8 \%$ & $23.3 \%$ \\
\hline
\end{tabular}

\begin{tabular}{|c|c|c|c|c|c|c|c|}
\hline \multicolumn{9}{|c|}{ Yes } & \multicolumn{4}{c|}{ Certainly } \\
\hline SV & H/A & Un & Ave & SV & H/A & Un & Ave \\
\hline $45.0 \%$ & $45.0 \%$ & $46.6 \%$ & $45.5 \%$ & $30.9 \%$ & $23.9 \%$ & $18.5 \%$ & $24.4 \%$ \\
\hline
\end{tabular}

\begin{tabular}{|c|c|c|c|c|c|c|c|c|c|c|c|}
\hline \multicolumn{1}{|c|}{ Table 4: Perceptions regarding the churches' preventative action } \\
\hline \multicolumn{1}{|c|}{ Certainly not } & \multicolumn{9}{|c|}{ No } & \multicolumn{4}{c|}{ Unsure } \\
\hline SV & H/A & Un & Ave & SV & H/A & Un & Ave & SV & H/A & Un & Ave \\
\hline $1.4 \%$ & $1.2 \%$ & $2.5 \%$ & $1.7 \%$ & $7.5 \%$ & $6.0 \%$ & $12.9 \%$ & $8.8 \%$ & $23.1 \%$ & $20.4 \%$ & $28.5 \%$ & $24.0 \%$ \\
\hline
\end{tabular}

\begin{tabular}{|c|c|c|c|c|c|c|c|}
\hline \multicolumn{9}{|c|}{ Yes } & \multicolumn{4}{c|}{ Certainly } \\
\hline SV & H/A & Un & Ave & SV & H/A & Un & Ave \\
\hline $47.3 \%$ & $48.6 \%$ & $36.4 \%$ & $44.1 \%$ & $20.7 \%$ & $23.8 \%$ & $19.7 \%$ & $21.4 \%$ \\
\hline
\end{tabular}

\begin{tabular}{|c|c|c|c|c|c|c|c|c|c|c|c|}
\hline \multicolumn{1}{|c|}{ Table 5: Perceptions regarding the churches' counselling } \\
\hline \multicolumn{1}{|c|}{ Certainly not } & \multicolumn{1}{|c|}{ No } & \multicolumn{5}{c|}{ Unsure } \\
\hline SV & H/A & Un & Ave & SV & H/A & Un & Ave & SV & H/A & Un & Ave \\
\hline $1.2 \%$ & $1.4 \%$ & $1.6 \%$ & $1.4 \%$ & $4.9 \%$ & $4.8 \%$ & $5.4 \%$ & $5.0 \%$ & $20.7 \%$ & $21.1 \%$ & $24.5 \%$ & $22.1 \%$ \\
\hline
\end{tabular}

\begin{tabular}{|c|c|c|c|c|c|c|c|}
\hline \multicolumn{9}{|c|}{ Yes } & \multicolumn{4}{c|}{ Certainly } \\
\hline SV & H/A & Un & Ave & SV & H/A & Un & Ave \\
\hline $52.0 \%$ & $50.7 \%$ & $51.3 \%$ & $51.3 \%$ & $21.2 \%$ & $22.0 \%$ & $17.2 \%$ & $20.1 \%$ \\
\hline
\end{tabular}

\begin{tabular}{|c|c|c|c|c|c|c|c|c|c|}
\hline \multicolumn{1}{|c|}{ Table 6: Statements regarding the churches' social involvement } \\
\hline \multicolumn{7}{|c|}{ Co-operation between churches } & \multicolumn{5}{c|}{ The churches do not care for the poor } \\
\hline $\begin{array}{c}\text { Disagree } \\
\text { Strongly }\end{array}$ & Disagree & Unsure & Agree & $\begin{array}{c}\text { Agree } \\
\text { Strongly }\end{array}$ & $\begin{array}{c}\text { Disagree } \\
\text { Strongly }\end{array}$ & Disagree & Unsure & Agree & $\begin{array}{c}\text { Agree } \\
\text { Strongly }\end{array}$ \\
\hline $0.8 \%$ & $0.4 \%$ & $7.3 \%$ & $43.2 \%$ & $48.3 \%$ & $22.9 \%$ & $32.2 \%$ & $22.0 \%$ & $15.9 \%$ & $6.9 \%$ \\
\hline
\end{tabular}

\begin{tabular}{|c|c|c|c|c|}
\hline \multicolumn{5}{|c|}{ The churches should co-operate with Gov/NGOs } \\
\hline $\begin{array}{c}\text { Disagree } \\
\text { Strongly }\end{array}$ & Disagree & Unsure & Agree & $\begin{array}{c}\text { Agree } \\
\text { Strongly }\end{array}$ \\
\hline $1.0 \%$ & $3.4 \%$ & $14.8 \%$ & $51.0 \%$ & $29.8 \%$ \\
\hline
\end{tabular}


(B) Results in percentage from the questionnaire survey in Paarl/Mbekweni (10\% sample): data on sexual and violent crime

\begin{tabular}{|c|c|c|c|c|c|c|}
\hline \multicolumn{7}{|c|}{ Table 7 } \\
\hline $\begin{array}{c}\text { Sample } \\
\text { Area }\end{array}$ & Table 7a: Involvement & \multicolumn{3}{|c|}{ Table 7b: Assistance received } \\
\hline $\mathrm{A}$ & $51.6 \%$ & $45.3 \%$ & $55.5 \%$ & $44.5 \%$ & $47.7 \%$ & $47.7 \%$ \\
\hline $\mathrm{AA}$ & $12.3 \%$ & $5.3 \%$ & $0.0 \%$ & $0.0 \%$ & $0.0 \%$ & $0.0 \%$ \\
\hline $\mathrm{AB}$ & $1.2 \%$ & $1.2 \%$ & $1.2 \%$ & $2.4 \%$ & $2.4 \%$ & $2.4 \%$ \\
\hline $\mathrm{AC}$ & $6.0 \%$ & $2.6 \%$ & $1.7 \%$ & $1.7 \%$ & $3.4 \%$ & $2.6 \%$ \\
\hline $\mathrm{AD}$ & $2.0 \%$ & $2.0 \%$ & $0.5 \%$ & $0.0 \%$ & $0.5 \%$ & $0.0 \%$ \\
\hline $\mathrm{B}$ & $40.3 \%$ & $39.6 \%$ & $39.6 \%$ & $40.3 \%$ & $44.3 \%$ & $45.0 \%$ \\
\hline $\mathrm{C}$ & $51.0 \%$ & $32.7 \%$ & $36.7 \%$ & $38.8 \%$ & $27.6 \%$ & $29.6 \%$ \\
\hline $\mathrm{D}$ & $27.9 \%$ & $21.1 \%$ & $26.5 \%$ & $28.6 \%$ & $20.4 \%$ & $27.2 \%$ \\
\hline $\mathrm{E}$ & $63.0 \%$ & $55.2 \%$ & $58.2 \%$ & $62.4 \%$ & $58.8 \%$ & $55.8 \%$ \\
\hline $\mathrm{F}$ & $42.9 \%$ & $25.7 \%$ & $38.6 \%$ & $24.3 \%$ & $21.4 \%$ & $31.4 \%$ \\
\hline $\mathrm{G}$ & $3.2 \%$ & $2.1 \%$ & $2.1 \%$ & $3.2 \%$ & $2.1 \%$ & $2.1 \%$ \\
\hline $\mathrm{H}$ & $3.9 \%$ & $6.5 \%$ & $1.3 \%$ & $5.2 \%$ & $3.9 \%$ & $3.9 \%$ \\
\hline $\mathrm{I}$ & $7.0 \%$ & $1.4 \%$ & $2.8 \%$ & $0.0 \%$ & $0.0 \%$ & $0.0 \%$ \\
\hline $\mathrm{J}$ & $1.0 \%$ & $1.0 \%$ & $1.0 \%$ & $1.0 \%$ & $1.0 \%$ & $1.0 \%$ \\
\hline $\mathrm{K}$ & $3.4 \%$ & $3.4 \%$ & $3.4 \%$ & $0.8 \%$ & $1.7 \%$ & $1.7 \%$ \\
\hline $\mathrm{M}$ & $4.8 \%$ & $6.3 \%$ & $3.2 \%$ & $4.0 \%$ & $4.8 \%$ & $3.2 \%$ \\
\hline $\mathrm{N}$ & $1.6 \%$ & $4.9 \%$ & $1.6 \%$ & $1.6 \%$ & $4.9 \%$ & $1.6 \%$ \\
\hline $\mathrm{O}$ & $0.0 \%$ & $0.0 \%$ & $0.0 \%$ & $0.0 \%$ & $0.0 \%$ & $0.0 \%$ \\
\hline $\mathrm{P}$ & $1.7 \%$ & $0.0 \%$ & $0.0 \%$ & $0.0 \%$ & $0.0 \%$ & $3.4 \%$ \\
\hline $\mathrm{Q}$ & $0.8 \%$ & $0.8 \%$ & $1.6 \%$ & $0.0 \%$ & $0.8 \%$ & $0.0 \%$ \\
\hline $\mathrm{R}$ & $10.6 \%$ & $3.3 \%$ & $5.6 \%$ & $3.3 \%$ & $0.6 \%$ & $0.6 \%$ \\
\hline $\mathrm{S}$ & $7.9 \%$ & $1.3 \%$ & $0.0 \%$ & $1.3 \%$ & $0.0 \%$ & $1.3 \%$ \\
\hline $\mathrm{T}$ & $6.2 \%$ & $6.2 \%$ & $4.1 \%$ & $1.4 \%$ & $1.4 \%$ & $1.4 \%$ \\
\hline $\mathrm{U}$ & $3.4 \%$ & $5.1 \%$ & $4.3 \%$ & $2.6 \%$ & $3.4 \%$ & $4.3 \%$ \\
\hline $\mathrm{V}$ & $2.5 \%$ & $5.9 \%$ & $2.5 \%$ & $7.6 \%$ & $10.2 \%$ & $5.1 \%$ \\
\hline $\mathrm{W}$ & $2.4 \%$ & $0.6 \%$ & $1.2 \%$ & $0.0 \%$ & $0.0 \%$ & $0.0 \%$ \\
\hline $\mathrm{X}$ & $0.0 \%$ & $0.0 \%$ & $0.0 \%$ & $0.0 \%$ & $0.0 \%$ & $0.0 \%$ \\
\hline $\mathrm{Y}$ & $1.3 \%$ & $0.6 \%$ & $0.0 \%$ & $0.0 \%$ & $0.6 \%$ & $0.0 \%$ \\
\hline $\mathrm{Z}$ & $2.9 \%$ & $5.1 \%$ & $4.0 \%$ & $1.1 \%$ & $2.9 \%$ & $2.3 \%$ \\
\hline$A-Z$ & $13.7 \%$ & $11.2 \%$ & $11.7 \%$ & $11.0 \%$ & $10.6 \%$ & $10.7 \%$ \\
\hline & & & & & & \\
\hline
\end{tabular}




\begin{tabular}{|l|c|c|c|c|c|}
\hline \multicolumn{7}{|l|}{ Table 8: Perceptions - Involvement with adult victims } \\
\hline $\begin{array}{l}\text { Sample } \\
\text { Area }\end{array}$ & $\begin{array}{c}\text { Certainly } \\
\text { not }\end{array}$ & No & Unsure & Yes & Certainly \\
\hline A & $1.72 \%$ & $1.72 \%$ & $13.79 \%$ & $51.72 \%$ & $31.03 \%$ \\
\hline AA & $0.00 \%$ & $0.00 \%$ & $0.00 \%$ & $100.00 \%$ & $0.00 \%$ \\
\hline AB & $0.00 \%$ & $2.94 \%$ & $11.76 \%$ & $67.65 \%$ & $17.65 \%$ \\
\hline AC & $1.82 \%$ & $7.27 \%$ & $21.82 \%$ & $34.55 \%$ & $34.55 \%$ \\
\hline AD & $0.00 \%$ & $2.17 \%$ & $19.57 \%$ & $52.17 \%$ & $26.09 \%$ \\
\hline B & $1.67 \%$ & $5.00 \%$ & $8.33 \%$ & $60.00 \%$ & $25.00 \%$ \\
\hline C & $6.33 \%$ & $2.53 \%$ & $17.72 \%$ & $45.57 \%$ & $27.85 \%$ \\
\hline D & $0.00 \%$ & $9.09 \%$ & $23.64 \%$ & $3.64 \%$ & $63.64 \%$ \\
\hline E & $4.84 \%$ & $3.23 \%$ & $19.35 \%$ & $38.71 \%$ & $33.87 \%$ \\
\hline F & $0.00 \%$ & $6.98 \%$ & $20.93 \%$ & $55.81 \%$ & $16.28 \%$ \\
\hline G & $0.00 \%$ & $18.60 \%$ & $27.91 \%$ & $41.86 \%$ & $11.63 \%$ \\
\hline H & $0.00 \%$ & $3.70 \%$ & $22.22 \%$ & $48.15 \%$ & $25.93 \%$ \\
\hline I & $0.00 \%$ & $0.00 \%$ & $48.28 \%$ & $27.59 \%$ & $24.14 \%$ \\
\hline J & $0.00 \%$ & $0.00 \%$ & $7.58 \%$ & $45.45 \%$ & $46.97 \%$ \\
\hline K & $0.00 \%$ & $2.56 \%$ & $17.95 \%$ & $56.41 \%$ & $23.08 \%$ \\
\hline M & $2.33 \%$ & $6.98 \%$ & $27.91 \%$ & $39.53 \%$ & $23.26 \%$ \\
\hline N & $0.00 \%$ & $6.25 \%$ & $15.63 \%$ & $50.00 \%$ & $28.13 \%$ \\
\hline O & $0.00 \%$ & $0.00 \%$ & $14.29 \%$ & $85.71 \%$ & $0.00 \%$ \\
\hline P & $0.00 \%$ & $0.00 \%$ & $27.59 \%$ & $55.17 \%$ & $17.24 \%$ \\
\hline Q & $0.00 \%$ & $5.13 \%$ & $17.95 \%$ & $66.67 \%$ & $10.26 \%$ \\
\hline R & $0.00 \%$ & $7.46 \%$ & $44.78 \%$ & $32.84 \%$ & $14.93 \%$ \\
\hline S & $2.86 \%$ & $14.29 \%$ & $17.14 \%$ & $37.14 \%$ & $28.57 \%$ \\
\hline T & $0.00 \%$ & $6.67 \%$ & $21.33 \%$ & $58.67 \%$ & $13.33 \%$ \\
\hline U & $0.00 \%$ & $6.00 \%$ & $24.00 \%$ & $44.00 \%$ & $26.00 \%$ \\
\hline V & $3.23 \%$ & $3.23 \%$ & $32.26 \%$ & $45.16 \%$ & $16.13 \%$ \\
\hline W & $0.00 \%$ & $4.23 \%$ & $19.72 \%$ & $54.93 \%$ & $21.13 \%$ \\
\hline X & $0.00 \%$ & $14.29 \%$ & $42.86 \%$ & $42.86 \%$ & $0.00 \%$ \\
\hline Y & $0.00 \%$ & $9.68 \%$ & $16.13 \%$ & $61.29 \%$ & $12.90 \%$ \\
\hline Z & $0.00 \%$ & $6.49 \%$ & $12.99 \%$ & $54.55 \%$ & $25.97 \%$ \\
\hline Average & $0.85 \%$ & $5.40 \%$ & $21.22 \%$ & $50.27 \%$ & $22.26 \%$ \\
\hline & & & & & \\
\hline
\end{tabular}

